\title{
Pengaruh Kompensasi terhadap Kinerja Karyawan CV. Riau Berlian Bagansiapiapi Kabupaten Rokan Hilir
}

\author{
LILI ERTI \\ Dosen Tetap Fakultas Ekonomi Universitas Lancang Kuning \\ Jln. Yos Sudarso KM 8 Rumbai \\ E-mail : lilierti@unilak.ac.id
}

\begin{abstract}
This research aims to determine the effect of compensation has a significant influence on employee performance CV. Riau Berlian Bagansiapiapi Rokan Hilir district. As for the population in this study are employees CV. Riau Berlian Bagansiapiapi Rokan 2015 as many as 33 people. Therefore pepulasinya bit then all the research sample population .. with the sampling technique is simple random sampling. Types and Sources of data collected are primary data and secondary data source directly from a questionnaire given to consumers / customers who are associated with this research. then the data is collected, tabulated and then were presented and analyzed in accordance with the purpose of research. Compensation may affect variabrel bound namely performance. Where the value of determination (R Square) of $0.476(47.6 \%)$ this shows that the rate of movement of the value of the dependent variable (compensation and working discipline) amounted to $47.6 \%$ and the remaining $52.4 \%$ is influenced by other factors not included in this research model. For thitung X (compensation) amounted to 5.302> 2.039, then Ho is rejected and H1 accepted, meaning a significant regression coefficient. So to compensate significantly have an impact on employee performance. Simultaneous testing overall value calculated F value of 28.111 while the F table at significant level (a) $5 \%$ is equal to 3.30 , the F count $>\mathrm{F}$ table. Or on the table looks significance of 0.000 for all variables, so that Ho refused and H1 accepted then it can be concluded that the compensation simultaneously have a significant impact on performance.
\end{abstract}

Keywords: organizational climate, motivation, job satisfaction

Keberhasilan suatu perusahaan sangat tergantung dengan kualitas sumber daya manusia yang mereka miliki dan bagaimana perusahaan tersebut mampu memenuhi segala sesuatu yang dapat memotivasi sumber daya manusia tersebut agar mereka mampu dan mau serta loyal memberikan yang terbaik untuk perusahaan tanpa ada paksaan. Selain itu, menempatkan mereka sebagai asset yang sangat penting yaitu sebagai faktor pertama dan utama dalam proses pembangunan.CV. Riau Berlian Bagansiapiapi Kabupaten Rokan Hilir kinerja karyawan dinilai sangat penting keberadaannya karena kinerja karyawan menentukan keberhasilan dalam mencapai tujuan perusahaan.

$\begin{array}{cccc}\text { Salah } & \text { satu usaha yang dapat } \\ \text { dilakukan } & \text { oleh pimpinan } & \text { untuk }\end{array}$ mengembalikan kondisi karyawan kepada situasi yang dapat menimbulkan kembali semangat dan kegairahan karyawan itu sendiri. Hal ini dapat dilakukan dengan jalan: Memperhatikan penghasilan yang wajar dan sesuai dengan status kepangkatan dan pengabdian karyawan kepada organisasi/instansi yang memungkinkan tercapainya dan tujuan organisasi/instansi secara efektif, termasuk didalamnya adalah pemberian insentif atau tambahan penghasilan sesuai dengan kemampuan organisasi. Memperhatikan kebutuhan rohani karyawan. Mengupayakan kondisi kerja yang baik, untuk menghindari kebosanan pegawai terhadap pekerjaan atau tugas. Melaksanakan penempatan pegawai sesuai dengan azas The Right Man in The Right Place. Memberikan kesempatan kepada pegawai untuk ikut memikirkan kemajuan organisasi dan kemjuan pribadinya demi perkembangan organisasi.

Bentuk kinerja karyawan pada CV.

Riau Berlian Bagansiapiapi Kabupaten Rokan Hilir yang ditemukan di lapangan 
antara lain bagaimana karyawan mampu menyelesaikan pelanggan yang menunggak atau bermasalah dengan pembayaran tagihan listrik yang dibayarkan kepada PLN

Berdasarkan survey pendahuluan pada beberapa karyawan di CV. Riau Berlian Bagansiapiapi Kabupaten Rokan Hilir penulis menemukan adanya permasalahan pada sistem pembayaran insentif, ada beberapa karyawan yang merasa diperlakukan kurang adil dengan sistem pemberiannya saat ini yang tidak mengarah pada beban kerja. Karyawan yang beban kerjanya tinggi dengan karyawan yang beban kerjanya rendah, menerima insentif yang sama. Padahal disisi pengorbanan, karyawan yang rajin sangat dirugikan. Selain itu fasilitas yang diterima karyawan masih kurang memadai, contohnya masih terdapat ruangan yang ukurannya kecil atau sempit yang dihuni oleh banyak karyawan yang membuat karyawan tidak nyaman berada diruangan tersebut.

Kompensasi merupakan kontra prestasi terhadap pengguna tenaga atau jasa yang telah diberikan oleh tenaga kerja (Wibowo;2011;348). Kompensasi adalah semua pendapatan yang berbentuk uang, barang langsung atau tidak langsung yang diterima karyawan sebagai imbalan atas jasa yang diberikan kepada perusahaan (Hasibuan;2007;118). Menurut Nurmansyah (2008;204) menyatakan bahwa kompensasi adalah segala sesuatu yang diterima para karyawan sebagai balas jasa atas kerja yang diberikannya kepada perusahaan berupa gaji, tunjangan, insentif, dan benefit. Kompensasi termasuk pengembalian jasa yang diberikan karyawan kepada perusahaan berupa finansial seperti gaji, tunjangan, bonus, insentif maupun non finansial seperti fasilitas, dan manfaat.

Tujuan pemberian kompensasi (balas jasa) antara lain adalah sebagai ikatan kerja sama, kepuasan kerja, pengadaan efektif, motivasi, stabilitas karyawan, disiplin, serta pengaruh serikat buruh dan pemerintah (Hasibuan;2007;121). Menurut Werther dan Davis (Wibowo;2011;350) Tujuan manajeman kompensasi adalah Memperoleh personil berkualitas, Mempertahankan karyawan yang ada, Memastikan keadilan, Menghargai perilaku yang diinginkan, Mengawasi biaya, Mematuhi peraturan, Efisensi administratif selanjutnya. Secara terinci, tujuan-tujuan yang hendak dicapai melalui administrasi kompensasi, Memperoleh personalia yang qualified, Mempertahankan para karyawan yang ada sekarang, Menjamin keadilan, Menghargai perilaku yang diinginkan, Mengendalikan biaya-biaya, Memenuhi peraturan-peraturan legal (Handoko;2011;156-158).

Kinerja berasal dari pengertian performance. Ada pula yang memberikan pengertian performance sebagai hasil kerja atau prestasi kerja. Tetapi, sebenarnya kinerja mempunyai arti yang lebih luas, bukan hanya hasil kerja, tetapi sebenarnya bagaimana proses suatu pekerjaan berlangsung. (Nurmansyah;2008;172) Pentingnya fungsi manajemen sumberdaya manusia tersebut dilakukan dengan baik, karena kontribusinya dalam peningkatan kemampuan organisasi dan berbagai komponennya, termasuk kesiapan para karyawan, untuk meningkatkan produktivitas kerjanya, (Siagian;2002;173)

Kinerja seseorang tenaga kerja atau karyawan dalam suatu organisasi atau instansi kerja, dipengaruhi oleh banyak factor, baik factor dari dalam karyawan itu sendiri maupun factor lingkungan atau organisasi kerja itu sendiri. Menurut, Gibson, Faktor-faktor yang menentukan kinerja seseorang, dikelompokan menjadi tiga factor utama yaitu : (Notoatmodjo; 2009;124), Variabel individu, yang terdiri dari : pemahaman terhadap pekerjaannya, pengalaman kerja, latar belakang keluarga, tingkat social ekonomi, dan factor demografi (umur,jenis kelamin, etnis, dan sebagainya). Variabel organisasi, yang antara lain terdiri dari : kepemimpinan, desain pekerjaan, sumber daya yang lain, struktur organisasi dan sebagainya. Variabel psikologis, yang terdiri dari persepsi terhadap pekerjaan, sikap terhadap pekerjaan, motivasi, kepribadian dan sebagainya.

p.ISSN: $2407-800 X \quad$ e.ISSN: $2541-4356$ 
Terdapat tujuh indikator kinerja, dua diantaranya mempunyai peran sangat penting, yaitu tujuan (goals) dan motif (motive). Kinerja ditentukan oleh tujuan yang hendak dicapai dan untuk melakukannya diperlukan adanya motif. Tanpa dorongan motif untuk mencapai tujuan, kinerja tidak akan berjalan. Dengan demikian, tujuan dan motif menjadi indikator utama dari kinerja, (Nurmansyah;2008;183-184)

\section{METODE}

Penelitian menggunakan pendekatan survey. Objek Penelitian ini adalah seluruh karyawan CV. Riau Berlian Bagansiapiapi Kabupaten Rokan Hilir yang berkantor pusat di Jl. Lintas Sumatra Kabupaten Rokan Hilir. Adapun yang menjadi populasi dalam penelitian ini adalah karyawan CV. Riau Berlian Bagansiapiapi Kabupaten Rokan tahun 2015 sebanyak 33 orang. Sampel dalam penelitian ini adalah seluruh karyawan CV. Riau Berlian Bagansiapiapi Kabupaten Rokan Hilir. Karena sedikitnya populasi maka seluruh populasi dijadikan sampel dalam penelitian ini.Teknik analisis data yang digunakan adalah analisis kuantitatif dengan program SPSS.

\section{HASIL}

Analisis ini berguna untuk mengetahui pengaruh antar variabel terikat secara individu terhadap variabel bebas tertentu. Sementara sejumlah variabel bebas lainnya yang ada atau diduga atau pertautannya dengan variabel terikat tersebut bersifat konstan atau tetap. ditarik kesimpulan antara variabel dimensi kompensasi terhadap kinerja diperoleh nilai b (koefisien regresi) untuk variabel kompensasi 0,569 , sedangkan constanta sebesar 7,955, sehingga diperoleh persamaan regresinya $\mathrm{Y}=7,955+0,569 \mathrm{X}$. Dari persamaan regresi menyatakan bahwa jika tidak ada kenaikan nilai dalam 7,955.

Dari persamaan regresi diatas, dapat di interpretasikan sebagai berikut : Nilai konstanta adalah 7,955 artinya tanpa adanya pengaruh kompensasi, maka kinerja karyawan sudah ada sebesar 7,955 satuan. Nilai koefisien regresi kompensasi adalah
0,569 artinya setiap peningkatan satu satuan kompensasi maka kinerja karyawan akan meningkat sebesar 56,9 satuan. Nilai variabel " $\mathrm{X}$ " menunjukkan, dimana t tabel 2,039 sementara itu dapat diambil keputusan : $\mathrm{t}$ hitung $\mathrm{X}$ (kompensasi) sebesar 5,302 > 2,039 maka Ho di tolak dan H1 diterima, artinya koefisien regresi signifikan.

Koefisien Determinasi (R2) adalah sebuah koefisien yang menunjukkan persentase pengaruh semua variabel independen terhadap variabel dependen. Persentase tersebut menunjukkan seberapa besar variabel independen (kompensasi) dapat menjelaskan variabel dependennya (kinerja). Semakin besar koefisien determiansinya, semakin setuju variabel dependen dalam menjelaskan variabel independennya. Dengan demikian persamaan regresi yang dihasilkan setuju untuk mengestimasi nilai variabel dependen.

Out put korelasi hasil pengolahan data menggunakan SPSS versi 17.00 dengan tingkat signifikan antara $1 \%$ hingga $5 \%$, tabel ini berisi tentang hubungan antara 3 variabel, analisanya sebagai berikut : Hubungan antara kompensasi (X) dengan variabel kinerja $(\mathrm{Y})$ adalah signifikan, hal ini terbukti dari angka signifikannya 0,000 jauh lebih rendah dari 0,05. Koefisien korelasinya adalah 0,690 dan bertanda positif (+) yang artinya kompensasi memiliki pengaruh yang sedang dan searah terhadap kinerja. Berdasarkan perhitungan nilai tersebut di atas diperoleh koefisien determinasi $\left(\mathrm{R}^{2}\right)$ sebesar 0,476 Hal ini menunjukkan bahwa kompensasi secara simultan memberikan pengaruh sebesar $47,6 \% \%$ terhadap kinerja, untuk sisanya $52,4 \%$ dipengaruhi oleh faktor lainnya.

\section{PEMBAHASAN}

Dari data yang diperoleh, diketahui bahwa keseluruhan jumlah karaywan yang ada pada CV. Riau Berlian Kabupaten Rokan Hilir adalah berjumlah 33 orang. Organisasi Kantor CV. Riau Berlian Bagan siapi api sangat membutuhkan tenaga yang

p.ISSN: 2407-800X e.ISSN: 2541-4356 
bertanggungjawab terhadap pelaksanaan tugas, oleh karena itu perlu didukung oleh adanya karyawan yang terampil serta memiliki kemampuan dan keahlian serta akuntabilitas kinerja yang tinggi dalam bekerja, sehingga dapat menimbulkan suatu sistem kerjasama yang serasi diantara pimpinan dengan pegawai maupun diantara sesama pegawai.

Untuk melihat keadaan pegawai pada CV. Riau Berlian Bagansiapiapi dalam melaksanakan tugas dan kinerja pemerintahan yang baik, berikut ini penulis kemukakan beberapa klasifikasi pegawai pada CV. Riau Berlian Bagansiapiapi, Berdasarkan data yang diperoleh, keadaan pegawai Kantor CV. Riau Berlian Bagansiapiapi saat ini didominasi oleh tingkat pendidikan menengah keatas, selanjutnya adalah karyawan dengan pendidikan D3 (Diploma 3). Untuk mengetahui Berdasarkan tabel diatas dapat diketahui bahwa Pegawai pada CV. Riau Berlian Bagansiapiapi sebagian besar yaitu 28 orang atau $85,85 \%$ berpendidikan SLTA atau Sederajat, 4 orang atau $12,12 \%$ berpendidikan D3 (Diploma 3), dan sebanyak 1 orang atau sekitar 3,03\% berpendidikan S1 (Sarjana). Dan belum ada karyawan pada CV. Riau Berlian Bagansiapiapi yang menamatkan pendidikan Pasca Sarjana ( S 2).

Adapun keadaan Pegawai pada CV. Riau Berlian Bagansiapiapi dilihat berdasarkan Jenis Kelamin adalah dapat dilihat bahwa dari 31 orang jumlah karyawan yang ada pada CV. Riau Berlian Bagansiapiapi pada tahun 2015, ada sejumlah 31 orang karaywan atau sekitar 93,94\% pegawai yang berjenis kelamin lakilaki dari keseluruhan karyawan yang ada. Sedangkan sisanya yaitu berjumlah 2 orang atau sekitar 6,06 adalah karaywan yang berjenis kelamin perempuan Masa kerja seseorang berpengaruh terhadap kemampuannya dalam melaksanakan tugas atau pekerjaan yang diberikan kepadanya. Semakin tinggi jam kerja seseorang maka pada umumnya kemampuan kerjanya juga akan meningkat.
Keadaan jumlah karyawan pada CV. Riau Berlian Bagansiapiapi berdasarkan masa kerja tersebut terlihat bahwa jumlah karyawanyang ada pada CV. Riau Berlian Bagansiapiapi mempunyai masa kerja 0 - 5 tahun berjumlah 17 orang atau 51,52\%. Masa kerja 6-10 tahun berjumlah 11 orang atau 33,33\%. Masa kerja 11-15 tahun 3 orang atau 9,09\%, kemudian 16 - 20 tahun sebanyak 1 orang atau 3,03 dan untuk masa kerja 20 tahun keatas hanya 1 orang atau $3,03 \%$ dari jumlah keseluruhan karyawan yang ada.

Karyawan dalam bekerja dituntut memiliki konsentrasi yang baik, sehingga pekerjaan yang dihasilkan sesuai dengan harapan dan tepat pada waktunya. Untuk melihat bagaimana keadaan karyawan pada CV. Riau Berlian Bagansiapiapi dilihat dari sisi status perkawinan, bahwa hampir seluruh karyawan pada CV. Riau Berlian Bagansiapiapi sudah menikah yaitu sebanyak 24 orang atau hampir 72,73\%, sedangkan karyawan yang belum kawin/nikah ada sebanyak 9 orang atau hampir 27,27\%. Kondisi ini tentunya berdampak terhadap semakin meningkatnya kebutuhan dari pada karyawan tersebut, yang selanjutnya akan berpengaruh pada tingkat akuntabilitas kinerja dari karyawan yang bersangkutan.

Kompensasi yang berarti imbalan berupa uang, ataupun bukan uang (natura), yang diberikan kepada karyawan dalam perusahaan atau organisasi pada periode yang tetap. Sistem kompensasi yang baik akan mampu memberikan kepuasan bagi karyawan dan memungkinkan perusahaan memperoleh, mempekerjakan, dan mempertahankan karyawan.

Sumber daya manusia merupakan satu-satunya sumber daya yang memiliki akal, perasaan, keinginan, kemampuan, keterampilan, pengetahuan, dorongan, daya, dan karya. Semua potensi sumber daya manusia tersebut sangat berpengaruh terhadap upaya organisasi dalam pencapaian tujuannya. Betapapun majunya teknologi, berkembangnya informasi, tesedianya modal dan memadainya bahan,

p.ISSN: $2407-800 X \quad$ e.ISSN: $2541-4356$ 
namun jika tanpa adanya sumberdaya manusia maka akan sulit bagi organisasi untuk mencapai tujuannya. Berdasarkan ketentuan umum pasa 1 Undang-Undang Tenaga Kerja Tahun 2003 No. 17, serikat buruh/srikat pekerja merupakan organisasi yang dibentuk dari, oleh, dan untuk pekerja baik di perusahaan maupun diluar perusahaan, yang bersifat bebas, terbuka, mandiri, demokratis, dan bertanggung jawab guna memperjuang, membela serta melindungi hak dan kepentingan pekerja serta meningkatkan kesejahteraan pekerja dan keluarga. Dari pengertian di atas, dapat di ketahui bahwa serikat pekerja memiliki fungsi dan pengaruh yang penting dalam membela dan melindungi hak dan kepentingan serta kesejahteraan pekerja dan keluarga.

Diketahui dari 33 responden yang menyatakan sangat sesuai 6 orang atau $18,18 \%$, yang menyatakan sesuai sebanyak 11 orang atau $33,33 \%$, yang menjawab cukup ssuai 7 oranga tau $21,21 \%$, dan 6 orang atau $18,18 \%$ menyatakan tidak sesuai serta 3 orang atau $9,09 \%$ menyatakan sangat tidak sesuai. Dari tabel di atas dapat disimpulkan bahwa pengawasan yang dilakukan serikat pekerja terhadap besarnya kompensasi yang diberikan perusahaan kepada karyawan dirasakan sudah sesuai.

Produktitas yaitu kuantitas dan efisiensi yang dihasilkan pekerjaan dalam periode waktu tertentu. Peningkatan yang terjadi pada prestasi karyawan secara perorangan pada akhirnya akan mendorong kinerja sumber daya manusia secara keseluruhan yang direfleksikan dalam kenaikan produktivitas. diketahui dari 33 responden yang menyatakan sangat sesuai 4 orang atau $12,12 \%$, yang menyatakan sesuai sebanyak 13 orang atau $39,39 \%$, yang menjawab cukup ssuai 8 orang atau $24,24 \%$, dan 5 orang atau $15,15 \%$ menyatakan tidak sesuai serta 3 orang atau $9,09 \%$ menyatakan sangat tidak sesuai. Dari ini dapat disimpulkan bahwa produktivitas karyawan sudah sesuai dengan pemberian kompensasi yang diberikan perusahaan atau yang diterima karyawan.
Kesediaan perusahaan untuk membayarkan kompensasi dalam rangka memberikan imbalan jasa apa yang dikerjakan oleh karyawan sangat tergantung dengan kemampuan yang dimiliki oleh perusahaan. diketahui dari 33 responden yang menyatakan sangat sesuai 4 orang atau $12,12 \%$, yang menyatakan sesuai sebanyak 8 orang atau $24,24 \%$, yang menjawab cukup ssuai 12 orang atau 36,36\%, dan 6 orang atau $18,18 \%$ menyatakan tidak sesuai serta 3 orang atau $9,09 \%$ menyatakan sangat tidak sesuai. Maka dapat disimpulkan bahwa kemampuan atau kesediaan untuk membayarkan kompensasi kepada karyawan menurut sebagian besar responden sudah tergolong cukup sesuai.

Kemampuan perusahaan untuk membayarkan kompensasi atau balas jasa kepada karyawan sangat ditentukan oleh kinerja atau apa yang dihasilkan karyawan untuk perusahaan. Kemampuan perusahaan sangat tergantung dengan apa yang dihasilkan oleh karyawan, atau bisa dikatakan kelanjutan hidup karyawan sangat tergantung dengan loyalitasnya karyawan terhadap perusahaan. diketahui dari 33 responden yang menyatakan sangat sesuai 7 orang atau 21,21\%, yang menyatakan sesuai sebanyak 15 orang atau $45,45 \%$, yang menjawab cukup ssuai 8 orang atau $24,24 \%$, dan 2 orang atau $6,06 \%$ menyatakan tidak sesuai serta 1 orang atau $3,03 \%$ menyatakan sangat tidak sesuai. Pada tabel di atas dapat disimpulkan kemampuan perusahaan untuk membayarkan kompensasi sudah tergolong sesuai dengan apa yang diberikan karyawan (dihasilkan).

Besaran balas jasa atau kompensasi yang diberikan pemerintah kepada karyawan sangat ditentukan dengan kebijakan delegurasi pemerintah, bisa diantaranya undang-undang yang antara lain UMR (Upah Minum Regional), penetapan besaran pajak penghasilan, kebijakan asuransi kesehatan yang sekarang sudah dimonopoli melalui BPJS. diketahui dari 33 responden yang menyatakan sangat sesuai 5 orang atau $15,15 \%$, yang 
menyatakan sesuai sebanyak 10 orang atau $30,30 \%$, yang menjawab cukup ssuai 15 orang atau $45,45 \%$, dan 2 orang atau $6,06 \%$ menyatakan tidak sesuai serta 1 orang atau 3,03\% menyatakan sangat tidak sesuai.

Manajemen Kinerja berkaitan dengan usaha, kegiatan atau program yang diprakarsai dan dilaksanakan oleh pimpinan organisasi untuk merencanakan, mengarahkan dan mengendalikan prestasi kerja karyawan. Karena program ini mencantumkan kata manajemen, maka seluruh kegiatan yang dilakukan dalam "proses manajemen" harus terjadi dimulai dengan menetapkan tujuan dan sasaran yang ingin dicapai, kemudian tahap pembuatan rencana, pengorganisasian, penggerakan/ pengarahan dan akhirnya evaluasi atas hasilnya.

Kualitas kinerja karyawan merupakan wujud perilaku yang tampak dari suatu kegiatan yang telah dilaksanakan, yang sesuai dengan harapan yang telah ditentukan sebelumnya. diketahui dari 33 responden yang menyatakan sangat sesuai 3 orang atau $9,09 \%$, yang menyatakan sesuai sebanyak 5 orang atau $15,15 \%$, yang menjawab cukup ssuai 17 orang atau $51,52 \%$, dan 5 orang atau $15,15 \%$ menyatakan tidak sesuai serta 3 orang atau $9,09 \%$ menyatakan sangat tidak sesuai.

Pengetahuan adalah informasi yang telah dikombinasikan dengan pemahaman dan potensi untuk menindaki; yang lantas melekat di benak seseorang. Pada umumnya, pengetahuan memiliki kemampuan prediktif terhadap sesuatu sebagai hasil pengenalan atas suatu pola. Manakala informasi dan data sekedar berkemampuan untuk menginformasikan atau bahkan menimbulkan kebingungan, maka pengetahuan berkemampuan untuk mengarahkan tindakan. Diketahui dari 33 responden yang menyatakan sangat sesuai 5 orang atau $15,15 \%$, yang menyatakan sesuai sebanyak 14 orang atau $42,42 \%$, yang menjawab cukup ssuai 11 orang atau 33,33\%, dan 3 orang atau 9,09\% menyatakan tidak sesuai.

Kepercayaan adalah tingkatan dimana karyawan dapat dipercaya berkaitan dengan Jurnal Daya Saing penyelesaian pekerjaan dan penindaklanjutannya. Optimalnya kinerja karyawan sangat dipengaruhi oleh kepuasan kerja karyawan. Kepuasan karyawan berpengaruh terhadap komitmen karyawan, serta prestasi kerja karyawan. Selain itu, karyawan yang puas sangat menguntungkan perusahaan sehingga mereka harus diberikan insentif-insetif yang dapat memicu semangat kerja serta membentuk kepuasan dalam bekerja. Karyawan yang tidak puas akan menyebabkan kekecewaan, hilangnya motivasi kerja, penurunan prestasi kerja, atau berujung karyawan meninggalkan pekerjaannya. diketahui dari 33 responden yang menyatakan sangat sesuai 9 orang atau $27,27 \%$, yang menyatakan sesuai sebanyak 10 orang atau $30,30 \%$, yang menjawab cukup ssuai 12 orang atau $36,36 \%$, dan 2 orang atau $8,06 \%$ menyatakan tidak sesuai.

Kinerja merupakan suatu fungsi dari motivasi dan kemampua. Untuk menyelesaikan tugas atau pekerjaan, seseorang harus memiliki derakat kesediaan dan tingkat kemampuan tertentu. Kesediaan dan keterampilan seseorang tidaklah cukup efektif untuk mengerjakan sesuatu tanpa pemahaman yang jelas tentang apa yang akan dikerjakan dan bagaimana mengerjakannya. diketahui dari 33 responden yang menyatakan sangat sesuai 8 orang atau 24,24\%, yang menyatakan sesuai sebanyak 11 orang atau $33,33 \%$, yang menjawab cukup ssuai 10 orang atau $30,30 \%$, dan 3 orang atau $9,09 \%$ menyatakan tidak sesuai serta 1 orang atau 3,03\% menyatakan sangat tidak sesuai.

Kebebasan adalah tingkat kinerja pekerjaan dengan sedikit atau tanpa supervisi. Karyawan membutuhkan spesifikasi. Informasi spesifik lengkap dengan cara pelaksanaan sangat membantu stabilitas kinerja, sekaligus memperbaiki kekurangan. Manajer tak perlu sibuk memandori dan karyawan tahu keinginan perusahaan, ini menunjang kreativitas. diketahui dari 33 responden yang menyatakan sangat sesuai 5 orang atau $15,15 \%$, yang menyatakan sesuai sebanyak

p.ISSN: $2407-800 X \quad$ e.ISSN: $2541-4356$ 
11 orang atau $33,33 \%$, yang menjawab cukup ssuai 14 orang atau $41,42 \%$, dan 2 orang atau $6,06 \%$ menyatakan tidak sesuai serta 1 orang atau 3,03\% menyatakan sangat tidak sesuai.

Kompensasi dapat mempengaruhi variabrel terikat yaitu kinerja. Dimana Nilai determinasi ( $\mathrm{R}$ Square) sebesar 0,476 $(47,6 \%)$ hal ini menunjukkan bahwa tingkat gerakan nilai variabel terikat (kompensasi dan disiplin kerja) sebesar 47,6\% dan sisanya $52,4 \%$ lagi dipengaruhi oleh faktor lain yang tidak dimasukkan ke dalam model penelitian ini Untuk $t_{\text {hitung }} \mathrm{X}$ (kompensasi) sebesar 5,302 > 2,039 maka Ho di tolak dan H1 diterima, artinya koefisien regresi signifikan. Maka untuk kompensasi secara signifikan memiliki pengaruh terhadap kinerja karyawan.

\section{SIMPULAN}

Berdasarkan hasil penelitian dan analisa yang penulis kemukakan pada babbab sebelumnya, maka dapat ditarik beberapa kesimpulan bahwa variabel kompensasi secara signifikan memiliki pengaruh terhadap kinerja karyawan.

\section{DAFTAR RUJUKAN}

Anoraga, Pandji, 2000. Manajemen Bisnis. Jakarta : PT Rineka Cipta.

Cardoso, Faustino, Gomes, 2003. Manajemen Sumber Daya Manusia. Yogyakarta : ANDI.

Hayati, Yayat, Djatmiko, 2004. Perilaku Organisasi, Bandung : Alfabeta.

Ivancevich, John, M, dkk. 2007, Perilaku dan Manajemen Organisasi. Jakarta: Penerbit Erlangga.

Komariah, Aan, dkk, 2004, Visionary Leadership Menuju Sekolah Efektif, Jakarta : Bumi Aksara.

Luthans, Fred. 2006. Perilaku Organisasi Edisi 10. Yogyakarta : Penerbit ANDI.

Manullang, M. 2008. Dasar-Dasar Manajemen. Yogyakarta : Gadjah Mada University Press.
Mondy, Wayne. E, SPHR. 2008. Manajemen Sumber Daya Manusia. Jakarta : Penerbit Erlangga.

Nurmansyah, Ec. 2010, Manajemen Sumber Daya Manusia Stategik. Pekanbaru: Unilak Press.

Notoatmodjo, $\quad$ Soekidjo. 2009. Pengembangan Sumber Daya Manusia. Jakarta : Rineka Cipta.

Rivai, Veithzal, dkk, 2009. Manajemen Sumber Daya Manusia untuk Perusahaan dari Teori dan Praktik. Jakarta : PT. Rajagrafindo Persada.

Russell, Edward - Walling, 2007, Terobosan Manajemen, yang perlu anda ketahui, Jakarta : Erlangga.

Sedarmayanti. 2001. Dasar-dasar Pengetahuan tentang Manajemen Perkantoran. Bandung : Mandar Maju.

Sinambela, Litjan Poltak., dkk. 2008. Reformasi Pelayanan Publik. Jakarta : Bumi Aksara.

Surya, H.M, dkk. 2006. Kapita Selekta Pendidikan SD. Jakarta : Universitas Terbuka Departemen Pendidikan Nasional.

Tangkilisan, Hessel Nogi. S. 2005. Manajemen Publik. Jakarta : PT. Gramedia Widiasarana Indonesia.

Teguh, Ambar, Sulistiyani Rosidah, 2009, Manajemen Sumber Daya Manusia, Yogyakarta : penerbit Graha Ilmu.

Uno. B. Hamzah, 2010. Teori Motivasi. Jakarta : Bumi Aksara. 